\title{
Prevalence of Caprine Subclinical Mastitis in Mymensingh Area, Bangladesh and Characterization of Associated Bacterial Agents and the Risk Factors
}

\author{
Khandkar Muhammad Alimul Razi, Md. Bahanur Rahman, Gerardo H. Flores-Gutiérrez ${ }^{1}$ and Md. Tanvir \\ Rahman* \\ Department of Microbiology and Hygiene, Faculty of Veterinary Science, Bangladesh Agricultural University, \\ Mymensingh-2202, Bangladesh. \\ ${ }^{1}$ Facultad de Medicina Veterinaria y Zootecnia "Dr. Norberto Treviño Zapata". Universidad Autónoma de Tamaulipas, \\ Victoria, Tamaulipas, México. \\ *Corresponding author's e-mail: tanvirahman@gmail.com
}

[Received: 21 April 2012, Revised: 15 May 2012, Accepted: 15 June 2012]

\begin{abstract}
A B S T R A C T
The prevalence of caprine subclinical mastitis in Mymensingh area was assessed by California Mastitis Test (CMT). Milk samples were also analyzed for the isolation and identification of bacterial agents that might be associated with caprine subclinical mastitis including their antibiotic sensitivity pattern against commonly used antibiotics. In addition, the influence of certain risk factors such as age of animal, parity, length of lactation period, type of farming system and type of housing floor, on the prevalence of caprine subclinical mastitis was also evaluated. Milk samples were collected from 59 goats (113 udder halves). The overall prevalence of caprine subclinical mastitis as determined by CMT was $18.64 \%$. On an udder half basis the prevalence was $15.04 \%$. Certain risk factors associated with caprine subclinical mastitis were identified. The prevalence was higher in older animals, with greater parity and longer lactation period. The prevalence was also higher in farms where goats were raised under traditional farming system with earthen floors. The predominant bacterial species isolated from milk that were collected from the subclinical mastitis positive cases were Staphylococcus aureus, S. epidermidis and Bacillus subtilis, that showed various degrees of sensitivity to the antibiotics used in the study.
\end{abstract}

Keywords: Subclinical mastitis, Caprine, Prevalence, Bacteria, Risk factors

(C) 2012 Microbes and Health. All rights reserved

\section{Introduction}

Mastitis refers to the inflammation of the udder. Mastitis is an important livestock disease and under untreated conditions, it constitutes a serious problem in dairy herds with considerable economic consequences, mainly due to fall in milk production, decreased milk quality for dairy purposes and poor milk hygiene; specially important when unpasteurized milk is used for cheese production (Seegers et al., 2003; Persson and Olofsson, 2011). In subclinical mastitis, there are no obvious clinical signs such as abnormal milk, udder swelling or tenderness, or systemic signs such as fever, depression. Instead there is an increase in somatic cell counts of the milk (Radostis et al., 1999).

Goats are one of the major sources of meat and dairy products in many areas of the world (Haenlein, 2004). In the last few years, an increase in the global goat population has been reported by FAO (2010). There are about 21.60 million goats in Bangladesh (DLS, 2009) and the

To cite this article: Razi KMA, MB Rahman, GH Flores-Gutiérrez and MT Rahman, 2012. Prevalence of caprine subclinical mastitis in Mymensingh area and characterization of associated bacterial agents and the risk factors Microbes Health, 1(1): 1-5. domestic goat farming has secured an important source of income for many farmers in this country. Goat milk production and processing worldwide is only about $2 \%$ of total milk production from all dairy animals combined (goats, sheep, buffaloes and cattle). However, goat milk production is of major economic importance in many countries including Bangladesh (55\% of all milk), Somalia (51\%), Mali (43\%), Indonesia (29\%), Greece (26\%), Iran (24\%), Sudan (16\%) and Algeria (13\%) (Haenlein, 1996). According to recent FAO (2010) report, Bangladesh remained in the top position for producing goat milk globally as it reached 2,168,000 tons in 2009. Therefore, any factor such as mastitis that adversely affects the quantity and quality of goat milk is of great financial interest in the goat rearing countries of the world including Bangladesh.

Several procaryotic and eucaryotic pathogens and predisposing factors have been identified that are associated with the onset of mastitis in goats (East et al., 1986; Contreras et al., 1995). In addition, several risk factors such as milking hygiene, management practice, stage of lactation and parity are also known to have influence on the occurrence of mastitis in goats (East et al., 1986; Boscos et al., 1996). While clinical mastitis is rather easy to detect, animals suffering from subclinical mastitis are often very 
difficult to find since there is a lack of reliable diagnostic methods, especially at farm level (Leitner et al., 2004). However, two indirect tests viz. somatic cell count and bacterial load count are accepted reliably for detecting the early infection (Schalm et al., 1971). In addition, other indirect tests like White Side Test and California Mastitis Test (CMT) have been developed for rapid screening of udder infection (Schalm et al., 1971; Guha et al., 1989). If the cases are not detected in time, subclinical mastitis may progress and develop into clinical cases (Adwan et al., 2005). Therefore, a rapid detection of udder health and the knowledge of risk factors are the basic requirements for the outcome of treatment to prevent the loss of milk production as well as prevent the spread of infection. Although many developing countries have proper strategies for this disease monitoring and control, there is little information available regarding the prevalence of subclinical mastitis in goats in Bangladesh. Therefore, the present study was carried out to determine the prevalence of subclinical mastitis in goat in Mymensingh and to identify and characterize the associated bacterial agents and the risk factors.

\section{Materials and Methods}

\section{Study area}

The present research work was carried out on Local and Crossbreed lactating goats from Goat and Sheep Breeding Farm at Bangladesh Agricultural University (BAU), and local farm around the BAU campus, Mymensingh during the period of August 2010 to April 2011.

\section{Collection of data and the milk samples}

A total of 113 udder halves milk samples were collected from 59 animals. No milk was available in other 5 udder halves. Milk samples were collected by soaking the teat with Povidone Iodine and drying off by disposable tissue paper. Initially, one to two drops of milk was discarded and then $5 \mathrm{ml}$ of milk was taken from each udder halves into sterilized test tubes with rubber cap. Each sample was labeled with an identification number. Data were also collected on age and parity of animals such as - how many times the animal gave birth to offspring, length of lactation period, type of farming system and type of floor in the farm (Table 2).

\section{Determination of subclinical mastitis}

Subclinical mastitis was determined by CMT using a CMT kit (Leucocytest ${ }^{\circledR}$, Synbiotics Corporation-2, Alexander Fleming -69007 Lyon, France) according to the instruction of the manufacturers. The CMT reagent reacts with DNA of epithelial and inflammatory cells present in the milk. CMT results were read immediately and were scored for each teat depending on the amount and thickness of gel formed. In this study, CMT scores of ' 0 ' and 'trace' were considered as negative or normal while CMT scores of $1+$ (weak positive), $2+$ (distinct positive) and $3+$ (strong positive) were taken as indicators of subclinical mastitis.

\section{Isolation and identification of bacterial agents}

Isolation of bacterial agents from the milk samples were carried out by culturing the milk samples on blood agar, McConkey agar, eosin methylene blue agar and nutrient agar plates. The inoculated plates were incubated at $37^{\circ} \mathrm{C}$ under aerobic condition for 24-48 hours. Identification of the bacterial agents from the pure culture were carried out based on their colony characteristics, Gram staining reaction, hemolysis pattern and biochemical test as described by Merchant and Packer (1967) and Cheesbrough (1985).

\section{Antimicrobials sensitivity tests}

Among the isolated bacterial agents, five isolates of Staphylococcus aureus, S. epidermidis and B. subtilis were selected randomly for the antibiogram study. Antibiotic sensitivity test of the selected bacterial isolates was performed by Disc Diffusion test according to the method described by Bauer et al. (1966). This method allowed the rapid determination of in vitro efficacy of an antibiotic by measuring the diameter of the zone of inhibition, which results from diffusion of the agent into the medium surrounding the disc. Ten commercially available antibacterial agents (Oxoid Ltd., UK) were selected for the purpose. The name of these antibacterial agents, their concentration per disc and the diameter of zone of inhibition that was used to interpret the data are presented in Table 1.

Table 1. Antibacterial agents used for the determination of antibiotic sensitivity pattern

\begin{tabular}{lcccc}
\hline $\begin{array}{l}\text { Antibacterial } \\
\text { agents }\end{array}$ & $\begin{array}{c}\text { Concen- } \\
\text { tration } \\
(\boldsymbol{\mu g} / \text { disc })\end{array}$ & \multicolumn{3}{c}{$\begin{array}{c}\text { Interpretation of results (Zone } \\
\text { diameter in mm) }\end{array}$} \\
\cline { 3 - 5 } & 30 & $\mathrm{R}$ & $\mathrm{I}$ & $\mathrm{S}$ \\
\hline Tetracycline & 10 & $\leq 14$ & $15-18$ & $\geq 19$ \\
Streptomycin & 10 & $\leq 11$ & $12-14$ & $\geq 15$ \\
Amoxicillin & 30 & $\leq 12$ & $12-14$ & $\geq 15$ \\
Chloramphenicol & 30 & $\leq 11$ & $12-15$ & $\geq 18$ \\
Cephalexin & 5 & $\leq 15$ & $16-20$ & $\geq 21$ \\
Ciprofloxacin & 10 & $\leq 12$ & $13-14$ & $\geq 15$ \\
Gentamicin & 30 & $\leq 14$ & $15-17$ & $\geq 18$ \\
Nalidixic acid & 30 & $\leq 12$ & $13-15$ & $\geq 16$ \\
Cephradine & 30 & $\leq 12$ & $13-14$ & $\geq 15$ \\
Kanamycin & \multicolumn{4}{l}{} \\
\hline$\mu$ g $=$ Microgram; mm = Millimeter; $\mathrm{S}=$ =Sensitive; I = intermediately \\
sensitive; R = Resistant
\end{tabular}

\section{Statistical analysis}

The main categorical variables of the analysed goats were classified in agreement with animals' age, parity, length of lactation period, farming system and type of floor. The prevalence of subclinical mastitis was determined using the positives and the total number of analyzed goats in each of the aforementioned variables (Table 2). In addition, the association between categorical variables and the presence of subclinical mastitis positive goats was carried out using a stratified cross-sectional design and calculating the adjusted prevalence ratio (PR). This analysis was obtained with the Win Episcope 2.0 (Veterinary School, Zaragoza, Spain) at a 95\% level of confidence (Table 2).

\section{Results}

\section{Prevalence of caprine subclinical mastitis}

In this study, among the 59 goats that were tested for the prevalence of subclinical mastitis by CMT, 11 were positive $(18.64 \%$ ). Udder half prevalence was $15.04 \%$ (Table 2 ). The association between the prevalence of subclinical mastitis was positively correlated with age. The prevalence of subclinical mastitis varied depending on the parity of the animal and length of their lactation period. The highest prevalence $(66.66 \%)$ was detected both at $6^{\text {th }}$ and $5^{\text {th }}$ parity, whereas lowest prevalence $(4.76 \%)$ was found at $2^{\text {nd }}$ parity, and the $4^{\text {th }}, 5^{\text {th }}$ and $6^{\text {th }}$ were considered as risk factors (Table 2). The highest prevalence of subclinical mastitis was detected in animals with a lactation period of 3-4 months, and the prevalence rate gradually decre- 
Table 2. Prevalence of subclinical caprine mastitis based on various parameters

\begin{tabular}{|c|c|c|c|c|c|}
\hline \multicolumn{2}{|l|}{ Parameters } & $\begin{array}{l}\text { No. of goat or sample } \\
\text { tested }\end{array}$ & $\begin{array}{l}\text { No. of positive cases } \\
\text { (Prevalence in \%) }\end{array}$ & Prevalence ratio (PR) & $P$ value \\
\hline \multicolumn{2}{|l|}{ Total animal tested } & 59 & $11(18.64)$ & & \\
\hline \multicolumn{2}{|c|}{ Milk samples (Quarter) } & 113 & $17(15.04)$ & & \\
\hline \multirow[t]{3}{*}{ Age } & 2-3 Year & 34 & $4(12.50)$ & 0.33 & $<0.0001$ \\
\hline & 3-4 Year & 20 & $5(25.00)$ & 1.22 & \\
\hline & 4-5 Year & 5 & $4(80.00)$ & 4.80 & \\
\hline \multirow[t]{6}{*}{ Parity } & $1 \mathrm{st}$ & 9 & 1 (11.11) & 0.56 & $<0.0001$ \\
\hline & 2nd & 21 & $1(4.76)$ & 0.18 & \\
\hline & $3 r d$ & 16 & $1(6.25)$ & 0.27 & \\
\hline & 4th & 7 & $4(57.14)$ & 4.25 & \\
\hline & 5 th & 3 & $2(66.66)$ & 4.15 & \\
\hline & 6th & 3 & $2(66.66)$ & 4.15 & \\
\hline \multirow{4}{*}{$\begin{array}{l}\text { Length of lactation } \\
\text { period }\end{array}$} & 0-1 month & 17 & $0(0)$ & 0 & 0.009 \\
\hline & $1-2$ month & 38 & $9(23.68)$ & 2.49 & \\
\hline & 2-3 month & 3 & $1(33.33)$ & 1.87 & \\
\hline & 3-4 month & 1 & $1(100)$ & 5.80 & \\
\hline \multirow[t]{2}{*}{ Farming system } & Traditional system & 33 & $8(24.24)$ & 2.10 & $<0.0001$ \\
\hline & Semi-intensive system & 26 & $3(11.53)$ & 0.48 & \\
\hline \multirow[t]{3}{*}{ Type of floor } & Slatted floor & 22 & $3(13.63)$ & 0.63 & $<0.0001$ \\
\hline & Concrete floor & 4 & $0(0)$ & 0 & \\
\hline & Earthen floor & 33 & $8(24.24)$ & 2.10 & \\
\hline
\end{tabular}

Here: If $\mathrm{PR}=1$, then there is no statistical association between disease and variables

If $P R>1$, then there is a positive association between disease and variables (risk factor)

If $\mathrm{PR}<1$, then there is a negative association between disease and variables (protective factor)

ased as the length of the lactation period shortened (Table 2). However, the lactation length of $0-1$ month was not associated with subclinical mastitis, while all the other lactation lengths were considered as risk factors (Table 2).

In this study, the prevalence of caprine subclinical mastitis was found to be influenced by farming system and type of floor used to raise the goat. The prevalence was higher, $24.24 \%$, and considered a significant risk factor in farms where goat was raised under a traditional farming system compared to $11.53 \%$ in semi-intensive farming system. The prevalence was also higher $(24.24 \%)$ in farms that had earth floor type compared to farms with slatted floors (13.63\%). Also, only the earthen floor housing was significantly associated with subclinical mastitis. None of the animals from a farm that had a concrete floor was found positive for subclinical mastitis.

\section{Isolation and identification of bacterial agents}

Seventeen milk samples from positive cases of subclinical mastitis were examined for the isolation and identification of bacterial agents. Among these 17 milk samples, 5 (29.41\%) were found positive for S. aureus. In addition, 3 samples $(17.64 \%)$ were positive for both $S$. epidermidis and $B$. subtilis (Table 3). Although most cases were associated with single infection, mixed infections with $S$. aureus and S. epidermidis or Gram-negative rod along with Bacillus sp. and a coccal pathogen were detected in few cases.

\section{Antibiotic sensitivity pattern of the bacterial agents}

The antibiogram study revealed that the isolated $S$. aureus were highly sensitive to amoxicillin, chloramphenicol and tetracycline and resistant to nalidaxic acid and streptomycin. Isolated $S$. epidermidis showed varying degrees of sensitivity to all the antibiotics used in this study with highest sensitivity to amoxicillin followed by tetracycline and ciprofloxacin. All the $B$. subtilis showed varying degrees of sensitivity to all the antibiotics used in this study with highest sensitivity to amoxicillin, ciprofloxacin, chloramphenicol and tetracycline. None of $S$. epidermidis and $B$. subtilis was resistant to any of the antibiotics used in this study.
Table 3. Prevalence of bacterial agents isolated from caprine subclinical mastitis milk samples

\begin{tabular}{lll}
\hline Bacterial isolates & $\begin{array}{l}\text { No of positive } \\
\text { cases }\end{array}$ & Prevalence (\%) \\
\hline Staphylococcus aureus & 5 & 29.41 \\
\hline Staph. epidermidis & 3 & 17.64 \\
\hline Bacillus subtilis & 3 & 17.64 \\
\hline S. aureus + S. epidermidis & 4 & 23.52 \\
\hline $\begin{array}{l}\text { Gram-negative rod } \\
+ \text { Bacilli }+ \text { Cocci }\end{array}$ & 2 & 11.76 \\
\hline
\end{tabular}

\section{Discussion}

In this study, the overall prevalence of subclinical mastitis was $18.64 \%$ by CMT in the goat population in Mymensingh area. On a udder half basis, the prevalence was $15.04 \%$. The prevalence of caprine subclinical mastitis in other countries such as in Brazil is $22.5 \%$ (Schmidt et al., 2009), in Pakistan is 13\% (Ali et al., 2010) and in Ethiopia is $18.03 \%$ (Gebrewahid et al., 2012). Recently, Islam et al., (2011) determined the prevalence of caprine subclinical mastitis in Savar area, Dhaka. The authors reported $34 \%$ prevalence of subclinical mastitis compared to $18.64 \%$ found in the present study. This observed variation in the prevalence of caprine subclinical mastitis in Bangladesh could be related with different managemental practices and two different locations of the study areas. The CMT was shown to be useful way for screening goats for the presence of increased somatic cell count and presence of an intramammary infection. However, at population level, false negative CMT results were observed (McDougall et al., 2010).

Age of animal was always been an important factor that govern the prevalence of subclinical mastitis in goat (Boscos et al., 1996; Sharma et al., 2007; Ali et al., 2010). In the present study, a trend in increase in the rate of prevalence of subclinical mastitis was observed as the age of the animal increased (Table 2). Higher age (3 years or above) was found epidemiologically associated with caprine subclinical mastitis. Our present findings support the earlier observations of Sharma et al. (2007) and Ali et al. (2010), who also observed an increased prevalence rate of subclinical mastitis in comparatively older goats. This 
increased prevalence of subclinical mastitis in older animal might be due to increased length of exposure of older animal to pathogens compared to younger animal. In addition, Ali et al. (2010) suggested that older animal are under stress resulting from long time milk production and multiple numbers of parturitions. As a result, such animals are easily become the host of infectious agents due to low immunity.

In the present study, the prevalence of subclinical mastitis was influenced by the parity of the animal and the length of lactation period. The prevalence of subclinical mastitis was higher in animals that were at later stage of their parity e.g., at the $6^{\text {th }}$ and $5^{\text {th }}$ parity, as reported earlier by Boscos et al. (1996). Sánchez et al. (1996) also reported parity as the risk factor for subclinical intramammary infection in goats. The highest prevalence of subclinical mastitis was also observed in animal that had a lactation period for 3-4 months.

Prevalence of caprine subclinical mastitis also appeared to be influenced by farm management system such as type of farming system and type of floor used to raise the goat in the studied area. In this study, the prevalence of subclinical mastitis was higher in farms where goat was raised under traditional conditions and had an earthen floor (soil surface). Earthen floor has been reported to be an important risk factor for subclinical mastitis in goat (Ndegwa et al., 2000). This observation could be explained by the fact that dirty and wet bedding, which was a common finding on the earthen floors, tends to harbor a wide range of infectious agents, which may contaminate the udder and the teats. Based on the findings of this study, we suggest to use semi-intensive farming system with either slatted floor or concrete floor to raise goats in order to reduce the prevalence of subclinical mastitis as these conditions appeared to be a protective factor (Table 2).

In the present study, among bacterial agents isolated from caprine milk samples that were found positive for subclinical mastitis, $S$. aureus was the most dominant species. About $29.41 \%$ of the milk samples were positive for $S$. aureus. The antibiogram study revealed that most of the isolated bacterial species were sensitive to various antibiotics used in the study at varying levels except the $S$. aureus, which was found resistant to nalidixic acid and streptomycin. All the tested isolated bacterial species were found highly sensitive to broad spectrum antibiotics such as amoxicillin, chloramphenicol, ciprofloxacin and tetracycline suggesting that these antibiotics could be the first choice of drug for the treatment purpose. Many authors reported antibiotic resistant strains of $S$. aureus as the dominant bacterial species frequently isolated from milk samples collected from subclinical caprine mastitis (Mhase et al., 2007; Ali et al., 2010; Gebrewahid et al., 2012). In addition, Islam et al. (2011) found $S$. aureus as the major etiological agent for subclinical mastitis in goat in Savar area of Bangladesh. S. aureus is probably the most infectious agent because it causes a chronic and deep infection in the mammary glands, which is extremely difficult to cure (Miles et al., 1992). Presence of $S$. aureus in the milk samples also has public health significance, since many of the $S$. aureus produce various enterotoxins that could result in food poisoning (Fagundes et al., 2010). Moreover, these $S$. aureus were found to be resistant to antibiotics thus making them more potential threats for farmers who are in close contact with these animals, since disease caused by them could be very difficult to treat. Due to their high contagious nature (Fox and Gay,1993), S. aureus could also easily be transmitted from infected animal to healthy animal through direct or indirect contact to cause disease, and thus require proper control strategies to prevent this agent from spreading to other does. A monitoring program to culture milk samples on regular basis might be a tool to detect the infected animal and separate them from the healthy animal to reduce the prevalence of subclinical mastitis in the healthy animal.

In addition to $S$. aureus, we also have identified $S$. epidermidis and Bacillus spp. from milk samples that were positive for caprine subclinical mastitis in this study. In caprine mastitis, S. epidermidis intramammary infections are associated with subclinical mastitis where it is identified in 20-30\% of cultured samples (Contreras et al., 2003). Bacillus spp. has also been identified from the caprine subclinical mastitis quite frequently (El Idrissi et al., 1994; Kostelić et al., 2009). In the present study, two milk samples were positive for Gram-negative rod along with other organisms. The ability of Gram-negative bacteria to induce mastitis in goat has earlier been reported by Ryan and Greenwood (1990) and Contreras et al. (1995).

Present study was carried out on a small population in Mymensingh. Further and intensive epidemiological studies should be carried at regional and national level to determine the prevalence of caprine subclinical mastitis, identification of the risk factors and characterization of the associated bacterial agents for the treatment and control of the disease.

\section{Conclusion}

The prevalence of subclinical mastitis in goats in Mymensingh area of Bangladesh was $18.64 \%$. S. aureus was the most common bacterial species associated with subclinical mastitis in goats in this vicinity. Certain risk factors as well as some protective factors associated with subclinical mastitis were identified. Age of the animal, parity, length of lactation period and housing system influenced the prevalence of subclinical mastitis status in goat population studied. Present findings suggest that application of broad spectrum antibiotic could be an effective way to control the disease along with some modifications in the farm management system.

\section{Acknowledgements}

We thank Prof. Larry Fox, College of Veterinary Medicine, Washington State University, USA for his critical comments and suggestions on the manuscript. We also thank the Government of the peoples republic of Bangladesh for providing NSICT fellowship to Razi KMA.

\section{References}

Adwan G, D Abusafieh, R Aref and JA Omar, 2005. Prevalence of microorganisms associated with intramammary infection in cows and small ruminants in the north of palestine. J Islamic Univ Gaza, 13: 165-173.

Ali Z, G Muhammad, T Ahmad, R Khan, S Naz, H Anwar, FA Farooqi, MN Manzoor and AR Usama, 2010. Prevalence of caprine subclinical mastitis, its etiologic- 
al agents and their sensitivity to antibiotics in indigenous breeds of Kohat, Pakistan. Pak J Life Sci, 8: 6367.

Bauer AW, WM Kirby, JC Sherris and M. Turck, 1966. Antibiotic susceptibility testing by a standardized single disk method. Am J Clin Pathol, 45: 493-496.

Boscos C, A Stefanakis, C Alexopoulos and F Samartzi, 1996. Prevalence of subclinical mastitis and influence of breed, parity, stage of lactation and mammary bacteriological status of Counter Counts and California Mastitis Test in the milk of Saanen and autochthonous Greek goats. Small Rumin Res, 21: 139147.

Cheesbrough M, 1985. Medical laboratory manual for tropical countries. Vol. II: Microbiology, pp: 400-480.

Contreras A, C Luengo, A Sánchez and JC Corrales, 2003. The role of intramammary pathogens in dairy goats. Livest Prod Sci, 79: 273-83.

Contreras A, JC Corrales, D Sierra and J Marco, 1995. Prevalence and aetiology of nonclinical intramammary infection in Murciano-Granadina goats. Small Rumin Res, 17: 71-78.

DLS, 2009. Directorate of Livestock Services, Khamer Bari Rd. Dhaka. (Personal communication).

Gebrewahid TT, BH Abera and HT Menghistu, 2012. Prevalence and etiology of subclinical mastitis in small ruminants of Tigray Regional State, North Ethiopia Vet World, 5: 103-109.

East NE, EF Birnie and TB Farver. 1986. Risk factors associated with mastitis in dairy goats. Am J Vet Res, 67: 63-67.

El Idrissi AH, A Benkirane and M Zardoune, 1994. Studies on subclinical mastitis in caprine dairy herds in Morocco. Rev Elev Med Vet Pays Trop, 47: 285-287.

Fagundes H, B Luciana, NF Antonio, Luciano, MF and AFO Carlos, 2010. Occurrence of Staphylococcus aureus in raw milk produced in dairy farms in São Paulo state, Brazil. Braz J Microbiol, 41: 376-380.

FAO, 2010. FAOSTAT. (http://faostat.fao.org/site/569/ Desktop Default.aspx?PageID=569\#ancor).

Guha C, AK Pramanik, SK Misra and AK Benarjee, 1989. Studies on the incidence and diagnosis of subclinical mastitis and clinical mastitis in goats and in vitro sensitivity of isolated pathogens. Ind Vet J, 68: 601604.

Haenlein GFW, 2004. Goat milk in human nutrition, Small Rumin Res, 51: 155-163.

Haenlein GFW, 1996. Nutritional value of dairy products of ewe and goat milk. In: Anifantakis, E.M. (Ed.), Proceedings of the IDF/CIRVAL seminar on production and utilization of ewe and goat milk. Int Dairy Fed, Brussels, Belgium, pp: 159-178.

Islam MR, MS Ahamed, MS Alam, MM Rahman, T Sultana, Y-S Roh and B Kim, 2011. Identification and antibiotic sensitivity of the causative organisms of sub- clinical mastitis in sheep and goats. Pak Vet J, 32: 179182.

Kostelić A, M Cergolj, B Tariba, V Rupić, M Benić, V Gantner and I Štoković, 2009. Prevalence and aetiology of subclinical mastitis in goats. Int J Anim Sci, 8: 134136.

Fox LK and JM Gay, 1993. Contagious mastitis. Vet Clin North Am Food Anim Pract, 9: 475-487.

Leitner G, U Merin, N Silanikove, E Ezra, M Chaffer, N Gollop, M Winkler, A Glickman and A Saran. 2004. A Effect of subclinical intramammary infection on somatic cell counts, NAGase activity and gross composition of goats' milk. J Dairy Res, 71: 311-315.

McDougall S, K Supré, S De-Vliegher, F Haesebrouck, H Hussein, L Clausen and C Prosser, 2010. Diagnosis and treatment of subclinical mastitis in early lactation in dairy goats. J Dairy Sci, 93: 4710-4721.

Merchant IA and RA Packer, 1967. Veterinary Bacteriology and Virology. $7^{\text {th }}$ Ed, The Iowa University Press, Ames, Iowa, USA, pp: 286-306.

Mhase PP, SD Harne and PR Suryawanshi, 2007. Aerobic bacterial flora of subclinical goat mastitis in Vidarbha region of Maharashtra. J Bombay Vet College, 15: 5051.

Miles H, W Lesser and P Sears, 1992. The economic implications of bioengineered mastitis control. J Dairy Sci, 75: 596-605.

Ndegwa EN, CM Mulei and SJ Munya, 2000. Risk factors associated with subclinical mastitis in Kenyan dairy goats. Israel J Vet Med, 56: 1-6.

Persson Y and I Olofsson, 2011. Direct and indirect measurement of somatic cell count as indicator of intramammary infection in dairy goats. Acta Vet Scand, 53: 15.

Radostis OM, CC Gay, DC Blood and KW Hinchcliff, 1999. Veterinary Medicine. A Textbook of the diseases of cattle, sheep, pigs, goats and horses. W. B. Saunders Co., Phila-delphia, Pennsylvania.

Ryan DP and PL Greenwood, 1990. Prevalence of udder bacteria in milk samples from four dairy goat herds. Aus Vet J, 67: 362-363.

Sánchez A, A Contreras and JC Corrales,1996. Parity as a risk factor for caprinesubclinical intramammary infection. Small Rumin Res, 21: 259-264.

Schalm OW, EJ Carroll and NC Jain, 1971. Bovine Mastitis. Lea and Febiger, Philadelphia, USA, pp: 360.

Schmidt V, AT Pinto, RN Schneider, FFP Da-Silva and FA De-Mello, 2009. Characterization of sub clinical mastitis in dairy goats herds raised on an organic system in Rio Grande do Sul. Pesq Vet Bras, 29: 774-778.

Seegers H, C Fourichon and F Beaudeau, 2003. Production effects related to mastitis and mastitis economics in dairy cattle herds. Vet Res, 34: 475-491.

Sharma SS, RK Tanwar, A Gahlot and AK Monika-Joshi, 2007. Somatic cell counts in relation to caprine subclinical mastitis. Ind J Vet Med, 27: 149-150. 